\title{
ANALISIS FUNGSI - FUNGSI MANAJEMEN TERHADAP KINERJA KARYAWAN PADA PT. MANDALA MULTI FINANCE KABUPATEN LUWU UTARA
}

\author{
Saharuddin ${ }^{*}$, I Ketut patra ${ }^{2}$, Sanaria ${ }^{1}$ \\ ${ }^{1}$ Sekolah Tinggi Ilmu Ekonomi Muhammadiyah Palopo \\ ${ }^{2}$ Sekolah Tinggi Ilmu Keguruan dan Ilmu Pendidikan \\ *saharuddin@stiem.ac.id
}

\begin{abstract}
The purpose of the study was to find out and analyze Management Functions of Employee Performance at PT. Mandala Multi Finance in North Luwu Regency. The research conducted was explanatory research and used a survey method. The study population is employees of PT. Mandala Multi Finance in North Luwu Regency which amounted to 15 people who were at the same time made samples in the study. The data analysis method used in this study is descriptive analysis and simple regression, where the independent variables in this study are management functions while the dependent variable is employee performance. The results of the study using simple regression analysis, namely management function variables have a positive and significant effect on employee performance at PT. Mandala Multi Finance in North Luwu Regency. This is indicated by the value of tcount $=4.110$ at the real level $(p=0.001<\alpha=0.05)$ or tcount (4.110) > t table $(2,179)$.
\end{abstract}

Keywords: Management functions and employee performance

\begin{abstract}
Abstrak
Tujuan penelitian adalah untuk mengetahui dan menganalisis Fungsi-Fungsi Manajemen Terhadap Kinerja Karyawan PT. Mandala Multi Finance di Kabupaten Luwu Utara. Penelitian yang dilakukan merupakan penelitian explanatory dan menggunakan metode survey. Populasi penelitian adalah Karyawan PT. Mandala Multi Finance di Kabupaten Luwu Utara yang berjumlah 15 orang yang sekaligus dijadikan sebagai sampel dalam penelitian. Metode analisis data yang dipergunakan dalam penelitian ini adalah analisis deskriptif dan Regresi Sederhana, dimana variabel independen didalam penelitian ini yaitu fungsi-fungsi manajemen sedangkan untuk variabel dependen yaitu kinerja karyawan. Hasil penelitian dengan menggunakan analisis regresi sederhana yaitu variabel fungsifungsi manajemen berpengaruh positif dan signifikan terhadap kinerja karyawan pada PT. Mandala Multi Finance di Kabupaten Luwu Utara. Hal ini di tunjukkan dari nilai thitung $=4,110$ pada taraf nyata $(\mathrm{p}=0,001<\alpha=0,05)$ atau $t_{\text {hitung }}(4,110)>t_{\text {tabel }}(2,179)$.

Kata Kunci: Fungsi-fungsi manajemen dan Kinerja Karyawan
\end{abstract}

\section{PENDAHULUAN}

Kunci utama yang mendukung organisasi berdaya saing tinggi terletak pada kinerja sumber daya manusia yang ada dalam organisasi yang bersangkutan, artinya apakah kinerja sumber daya manusianya dapat memenuhi tuntutan persaingan global ataukah sebaliknya.Atas dasar hal tersebut, maka tidak dapat dipungkiri dukungan dan peningkatan kualitas sumber daya manusia merupakanprioritas dan tantangan yang harus dihadapi dalam menyambut era globalisasi.

Keberhasilan sebuah perusahaan tidak lepas dari peran serta sumberdaya manusianya, karena hampir seluruh kegiatan operasional dilakukan oleh manusia. Sehingga peran SDM sangat penting untuk menunjang kelancaran semua aktivitas didalam seluruh operasional perusahaan tersebut.
SDM memerlukan pengelolaan yang tepat terutama antara lain dengan menerapkan fungsifungsi manajemen. Fungsi-fungsi manajemen meliputi perencanaan, pengarahan, pengorganisasian, dan pengendalian atas keputusan-keputusandan tindakan-tindakan perusahaan yang berkaitan dengan strategi.Strategi diartikan oleh para manajer sebagai rencana mereka yang berskala besardan berorientasi kepada masa depan untuk berinteraksi dengan lingkunganpersainganguna mencapai sasaransasaran perusahaan.

Fungsi-fungsi manajemen merupakan kegiatan yang harus dilaksanakan dalam sebuah organisasi untuk mencapai tujuan yang diinginkan berdasarkan tingakatan-tingkatan yang telahdiberikan kepada yang menjalankan kegiatan fungsi manajemen tersebut, dan juga merupakan 
kegiatan yang dilakukan oleh karyawan baik itu fungsimanajerial maupun fungsi operatif (teknis), yang pada hakikatnya bertujuan untukmelakukan kegiatan-kegiatan dengan pekerjaan yang dijabat seseorang.

PT. Mandala Luwu Utara merupakan suatu organisasi yang bergerak dibidang pembiayaan, dimana PT. Mandala merupakan salah satu organisasi pembiayaan yang memiliki tingkat nasabah terbanyak di Kabupaten Luwu Utara. Maka penting bagi suatu organisasi dalam hal ini PT. Mandala Luwu Utara untuk mengetahui sejauhmana keefektifan penerapan karyawannya dalam melaksanakan fungsi-fungsi manajemen didalam perusahaan. Berdasarkan latar belakang yang telah dipaparkan, maka peneliti tertarik untuk mengangkat judul yaitu Analisis Fungsi-Fungsi Manajemen Terhadap Kinerja Karyawan Pada PT. Mandala Putera di Kabupaten Luwu Utara.

\section{KAJIAN PUSTAKA}

Dari pendapat mengenai fungsi manajemen di atas, secara keseluruhan menempatkan perencanaan (Planning) pada urutan paling atas, dengan demikian para ahli menempatkan perencanaan hal paling penting dalam fungsi manajemen.

Sedangkan pengertian manajemen adalah merupakan suatu usaha seni, kemahiran penerapan ilmu pengetahuan dalam pelaksanaan kegiatan untuk mencapai tujuan yang dikehendaki. Seperti yang dikemukakan oleh Ritonga (2004) bahwa manajemen dapat ditinjau dari dua segi, pertama ; dari segi ilmu yaitu merupakan suatu kenyataan data informasi mengenai tata kerjasama yang merupakan obyek study. Kedua ; dari segi seni yaitu merupakan siasat dan usaha tata kerjasama untuk mencapai tujuan tertentu. Ritonga (2004), mendefenisikan manajemen adalah suatu sistem tingkahlaku manusia yang kooperatif, yang dipimpin secara teratur melalui usaha yang terus menerus dan merupakan tindakan rasional.

$$
\text { Ritonga (2004) mendefenisikan }
$$

manajemen sebagai bidang pengetahuan yang berusaha memahami mengapa dan bagaimana orang bekerja sama untuk mencapai tujuan.

Istilah manajemen memiliki berbagai pengertian. Secara universal manajemen adalah penggunaan sumberdaya organisasi untuk mencapai sasaran dan kinerja yang tinggi dalam berbagai tipe organisasi profit maupun non profit. Dan manajemen itu sendiri berkaitan erat dengan style, seni dan proses yang hidup dan dinamis dalam lingkup organisasi dalam upayanya untuk mencapai tujuan serta bagaimana tujuan tersebut dapat dicapai secara efektif dan efisien.

\section{Kinerja Karyawan Pengertian Kinerja Karyawan}

Untuk memberikan batasan mengenai kinerja biasa dilakukan dari berbagai sudut pandang sesuai dengan tujuan masing-masing organisasi (misalnya untuk profit, untuk custumer satisfaction) juga tergantung pada bentuk organisasi itu sendiri (misalnya organisasi publik versus organisasi swasta, atau organisasi bisnis ataukah organisasi sosial). Menurut Mangkunegara (2001;67) kinerja adalah hasil kerja secara kualitas dan kuantitas yang dicapai oleh seorang pegawai dalam melaksanakan tugasnya sesuai dengan tanggung jawab yang diberikan kepadanya.

Berbagai ungkapan seperti output, kinerja (performance), efisiensi, efektivitas mempunyai hubungan dengan kinerja. Secara umum, pengertian kinerja dikemukakan orang dengan menunjukkan kepada rasio output terhadap input. ada yang melihat performance dengan memberikan penekanan pada nilai efisiensi, efisiensi diukur sebagai rasio output terhadap input.

Ada yang melihat performance dengan memberikan penekanan pada nilai efisiensi, efisiensi diukur sebagai rasio output terhadap input. Dengan kata lain, pengukuran efisiensi menghendaki penentuan outcome dan penentuan jumlah sumber daya yang dipakai untuk menghasilkan outcome tersebut.

Sedangkan Malayu S.P. Hasibuan (2001:34) mengemukakan "kinerja (prestasi kerja) adalah suatu hasil kerja yang dicapai seseorang dalam melaksanakan tugas-tugas yang dibebankan kepadanya yang didasarkan atas kecakapan, pengalaman dan kesungguhan serta waktu".

August Smith (Sedarmayanti, 2001:57), menyatakan bahwa kinerja adalah hasil atau keluaran dari suatu proses. Kinerja memilki hubungan yang erat dengan produktifitas, karena merupakan indicator dalam menentukan bagaimana 
usaha untuk mencapai tingkat produktivitas yang tinggi dalam suatu organisasi.

\section{Penilaian Kinerja}

Dalam penetapan kinerja individu, merupakan salah satu masalah yang pokok dalam pengukuran kinerja organisasi, sebab jika kita lihat secara umum kinerja berkaitan dengan individu seseorang pegawai dan juga organisasi. Menurut Mangkunegara (2001;67) kinerja adalah hasil kerja secara kualitas dan kuantitas yang dicapai oleh seorang pegawai dalam melaksanakan tugasnya sesuai dengan tanggung jawab yang diberikan kepadanya.

Perencanaan sumber daya manusia atau perencanaan tenaga kerja merupakan serangkaian kegiatan yang dilakukan untuk mengantisipasi permintaan-permintaan bisnis dan lingkungan pada organisasi diwaktu yang akan datang dan untuk memenuhi kebutuhan kebutuhan tenaga kerja yang ditimbulkan oleh kondisi-kondisi tersebut.

Adapun pengertian dari pelaksanaan yaitu tahapan dimana dan kapan, bagaimana dengan siapa program kegiatan tersebut akan dilaksakan. Sementara evaluasi dapat pula diartikan sebagai salah satu fungsi dari manajemen, evaluasi dilakukan terhadap seluruh atau sebagian unsurunsur program serta terhadap pelaksanaan program, evaluasi dapat dilakukan secara terus menerus, berkala dan atau sewaktu-waktu pada saat sebelum, sedang dan atau setelah program dilaksanakan.

Pengaruh Hubungan Antar Variabel FungsiFungsi Manajemen Terhadap Kinerja Karyawan

Hasil peneltian yang dilakukan oleh Elfian (2013) dengan judul penelitian yaitu pengaruh penerapan fungsi-fungsi manajemen terhadap kinerja guru pada SDN 143 Arusu Kecamatan Malangke Barat Kabupaten Luwu Utara. Hasil penelitian menunjukkan bahwa secara parsial (Ujit) bahwa variabel Fungsi-Fungsi Manajemen yang terdiri dari Planninig, Organization, Actuating, Controlling berpengaruh positif signifikan terhadap Kinerja Guru.

\section{METODE}

Lokasi yang dipilih oleh peneliti PT. Mandala di Kabupaten Luwu Utara dengan waktu yang digunakan dalam penelitian ini adalah \pm 3 Bulan (Januari - Maret tahun 2014). Adapun populasi yang digunakan didalam penelitian ini adalah seluruh karyawan PT. Mandala Multi Finance di Kabupaten Luwu Utara yang berjumlah 15 orang, yang sekaligus dijadikan sebagai sampel dalam penelitian. Data yang digunakan dua jenis data yaitu daata Primer yang diperoleh dari hasil observasi dan wawancara langsung dengan pimpinan dan staf karyawan pada saat melakukan penelitian dan data Sekunder, yaitu data tertulis yang diperoleh dari PT. Mandala di Kabupaten Luwu Utara berupa literatur-literatur dan laporan.

Data dianalisis secara deskriptif dan dilakukan uji validitas dan reliabilitas.

\section{Uji Validilitas}

Setelah data dikumpulkan, maka pengujian validitas dilakukan dengan mengkorelasi skor-skor tiap item pertanyaan dengan skor total. Analisis korelasi dilakukan dengan rumus korelasi product moment pearson (Adi Riyanto Suprayitno dan Sapar,2011:42). Adapun rumus dari korelasi product moment pearson sebagai berikut:

$$
r=\frac{n\left(\sum X Y\right)-\left(\sum X \sum Y\right)}{\sqrt{\left.\left[n X^{2}-\left(\sum X\right)^{2}\right] n \sum Y^{2}-\left(\sum Y\right)^{2}\right]}}
$$

Dimana :

$$
\begin{array}{lll}
\mathrm{r} & =\text { korelasi product moment } \\
\text { pearson } & \\
\mathrm{X} & =\text { skor pernyataan } \\
\mathrm{Y} & =\text { skor total } \\
\mathrm{XY} & =\text { skor pernyataan } \\
\mathrm{n} & =\text { total penyataan }
\end{array}
$$

\section{Uji Reliabilitas}

Reliabilitas atau keandalan dilakukan untuk mengetahui sampai sejauh mana kuesioner yang diajukan dapat memberikan hasil yang tidak berbeda jika dilakukan pengukuran kembali terhadap subjek yang sama pada waktu berlainan. Suatu kuesioner disebut mempunyai reliabilitas atau dapat dipercaya, jika kuesioner itu stabil, dan dapat diandalkan sehingga penggunaan kuesioner tersebut berkali-kali akan memberikan hasil yang serupa. 
Menurut (Imam Ghozali, 2006) pengukuran reliabilitas dapat dilakukan dengan cara One Shot atau pengukuran sekali saja: Disini pengukurannya hanya sekali dan kemudian hasilnya dibandingkan dengan pertanyaan lain atau mengukur reliabilitas dengan uji statistic Cronbach Alpha (á). Suatu konstruk atau variabel dikatakan reliable jika memberikan nilai Cronbach Alpha $>0,60$. Adapun hasil perhitungan reliabilitasnya yaitu:

\section{Analsis Regresi Sederhana}

Adapun metode analisis yang digunakan adalah menggunakan metode analisis regresi sederhana dengan formulasi matematis sebagai berikut (Suliyanto,2011):

$$
\mathbf{Y}=\mathbf{a}+\mathbf{b X}+\mathbf{e}
$$

Di mana :

$$
\begin{array}{ll}
\mathrm{Y} & =\text { Kinerja Karyawan PT. Mandala } \\
\mathrm{a} & =\text { Nilai intersepsi (konstanta) } \\
\mathrm{b} & =\text { Koefisien regresi } \\
\mathrm{X} & =\text { Fungsi-Fungsi Manajemen } \\
e & =\text { error (tingkat kesalahan) }
\end{array}
$$

\begin{tabular}{|c|c|c|c|c|c|c|c|c|c|c|c|c|}
\hline \multirow{3}{*}{ No } & \multirow{3}{*}{$\begin{array}{c}\text { Item } \\
\text { Pernyataan }\end{array}$} & \multicolumn{10}{|c|}{ Tanggapan Responden } & \multirow{3}{*}{$\mathbf{N}$} \\
\hline & & \multicolumn{2}{|c|}{ SS (5) } & \multicolumn{2}{|c|}{$S(4)$} & \multicolumn{2}{|c|}{$\mathbf{R}(3)$} & \multicolumn{2}{|c|}{ KS (2) } & \multicolumn{2}{|c|}{ STS (1) } & \\
\hline & & $\mathbf{F}$ & $\%$ & $\mathbf{F}$ & $\%$ & $\mathbf{F}$ & $\%$ & $\mathbf{F}$ & $\%$ & $\mathbf{F}$ & $\%$ & \\
\hline 1 & PLN1 & 2 & 13,3 & 12 & 80,0 & 0 & 0 & 1 & 6,7 & 0 & 0 & 15 \\
\hline 2 & PLN2 & 3 & 20,0 & 11 & 73,3 & 0 & 0 & 1 & 6,7 & 0 & 0 & 15 \\
\hline 3 & PLN3 & 5 & 33,3 & 7 & 46,7 & 2 & 13,3 & 0 & 0 & 1 & 6,7 & 15 \\
\hline 4 & PLN4 & 6 & 40,0 & 7 & 46,7 & 0 & 0 & 2 & 13,3 & 0 & 0 & 15 \\
\hline 5 & PLN5 & 6 & 40,0 & 8 & 53,3 & 0 & 0 & 0 & 0 & 1 & 6,7 & 15 \\
\hline 6 & 01 & 2 & 13,3 & 11 & 73,3 & 0 & 0 & 1 & 6,7 & 1 & 6,7 & 15 \\
\hline 7 & 02 & 1 & 6,7 & 11 & 73,3 & 1 & 6,7 & 1 & 6,7 & 1 & 6,7 & 15 \\
\hline 8 & 03 & 5 & 33,3 & 5 & 33,3 & 3 & 20,0 & 1 & 6,7 & 1 & 6,7 & 15 \\
\hline 9 & PLKS1 & 2 & 13,3 & 12 & 80,0 & 0 & 0 & 1 & 6,7 & 0 & 0 & 15 \\
\hline 10 & PLKS2 & 1 & 6,7 & 12 & 80,0 & 1 & 6,7 & 1 & 6,7 & 0 & 0 & 15 \\
\hline 11 & PLKS3 & 4 & 26,7 & 6 & 40,0 & 3 & 20,0 & 1 & 6,7 & 1 & 6,7 & 15 \\
\hline 12 & PNGD1 & 2 & 13,3 & 10 & 66,7 & 0 & 0 & 3 & 20,0 & 0 & 0 & 15 \\
\hline 13 & PNGD2 & 1 & 6,7 & 12 & 80,0 & 1 & 6,7 & 0 & 0 & 1 & 6,7 & 15 \\
\hline 14 & PNGD3 & 3 & 20,0 & 10 & 66,7 & 0 & 0 & 1 & 6,7 & 1 & 6,7 & 15 \\
\hline 15 & PNGD4 & 4 & 26,7 & 8 & 53,3 & 2 & 13,3 & 1 & 6,7 & 0 & 0 & 15 \\
\hline
\end{tabular}

Tabel. 1 Tanggapan Respoden Terhadap Variabel Fungsi-Fungsi Manajemen

Sumber : Lampiran 3 ,diolah, 2014

Tanggapan responden terhadap pernyataan (PLN3) "Program perencanaan pengembangan karyawan sudah sesuai dengan kualifikasi

\section{HASIL DAN PEMBAHASAN}

Dalam mendeskripsikan variabel fungsifungsi manajemen maka dapat dilihat pada frekuensi hasil tanggapan responden terhadap masing-masing pertanyaan atau item yang digunakan untuk mengukur variabel fungsi-fungsi manajemen dan hasilnya terdapat dalam tabel 3 .

Berdasarkan tabel 1 dapat dideskripsikan tanggapan responden terhadap item-item variabel orientasi pelanggan . Tanggapan responden terhadap pernyataan (PLN1) "Anda terlibat aktif dalam setiap penyusunan perencanaan program pekerjaan" sebagian besar responden menyatakan setuju yaitu sebanyak 12 atau $(80,0 \%)$.

Tanggapan responden terhadap pernyataan (PLN2) "Pimpinan anda mampu merencanakan dan memimpin atas seluruh perencaan yang telah disusun" sebagian besar responden menyatakan setuju yaitu sebanyak 11 atau $(73,3 \%)$. 
pekerjaan anda" sebagian besar responden menyatakan setuju yaitu sebanyak 7 atau $(46,7 \%)$.

Tanggapan responden terhadap pernyataan (PLN4) "Penysusunan pelaksaan program kerja disesuaikan dengan tingkat pendidikan karyawan" sebagian besar responden menyatakan setuju yaitu sebanyak 7 atau $(46,7 \%)$.

Tanggapan responden terhadap pernyataan (PLN5) "Pimpinan anda menyusun perencanaan kerja pada karyawan untuk meningkatkan profesionalisme dan mutu serta kualitas kerja" sebagian besar responden menyatakan setuju yaitu sebanyak 8 atau $(53,3 \%)$.

Tanggapan responden terhadap pernyataan (O1) "Pimpinan anda mampu mengorganisasikan seluruh program kerja yang telah direncanakan" sebagian besar responden menyatakan setuju yaitu sebanyak 11 atau $(73,3 \%)$.

Tanggapan responden terhadap pernyataan (O2) "Pimpinan anda mampu mengorganisasikan dan memimpin program pengembangan karyawan" sebagian besar responden menyatakan setuju yaitu sebanyak 11 atau $(73,3 \%)$.

Tanggapan responden terhadap pernyataan (O3) "Anda terlibat aktif dalam pengorganisasian program pekerjaan" sebagian besar responden menyatakan sangat setuju dan setuju yaitu sebanyak 5 atau $(33,5 \%)$.

Tanggapan responden terhadap pernyataan (PLKS1) "Pimpinan anda mampu merealisasikan setiap program kerja yang telah direncanakan dan diorganisasikan" sebagian besar responden menyatakan setuju yaitu sebanyak 12 atau $(80,0 \%)$.

Tanggapan responden terhadap pernyataan (PLKS2) "Setia perencanaan yang dibuat mampu dilaksanakan dengan baik oleh setiap karyawan dan pimpinan sesuai dengan tujuan organisasi" Asebagian besar responden menyatakan setuju yaitu sebanyak 12 atau $(80,0 \%)$.

Uji validitas dan reliabilitas indikator Kinerja Karyawan dapat dilihat pada Tabel 2

Tabel. 2 Uji Validitas dan Reliabilitas Kinerja Karyawan (Y)

\begin{tabular}{lccccc}
\hline \multirow{2}{*}{ No } & Item & \multicolumn{2}{c}{ Uji Validitas } & \multicolumn{2}{c}{ Uji Reliabilitas } \\
\cline { 3 - 5 } & Pertanyaan & $\begin{array}{c}\text { Koefisien } \\
\text { Korelasi }\end{array}$ & Kategori & $\begin{array}{c}\text { Cronbach } \\
\text { Alpha }\end{array}$ & Kategori \\
\hline 1 & KST1 & 0,713 & Valid & \\
2 & KST2 & 0,830 & Valid & \\
3 & KST3 & 0,594 & Valid & \\
4 & KST4 & 0,596 & Valid & \\
5 & KST5 & 0,780 & Valid & \\
6 & KRJ1 & 0,919 & Valid & \\
7 & KRJ2 & 0,839 & Valid & \\
8 & KRJ3 & 0,839 & Valid & 0,945 & \\
9 & KRJ4 & 0,702 & Valid & \\
10 & KRJ5 & 0,812 & Valid & \\
11 & TJ1 & 0,791 & Valid & \\
12 & TJ2 & 0,734 & Valid & \\
13 & TJ3 & 0,972 & Valid & \\
14 & TJ4 & 0,555 & Valid & \\
15 & TJ5 & 0,581 & Valid & \\
\hline
\end{tabular}

Sumber: Lampiran 4 dan 5. Uji Validitas dan Reliabilitas

Berdasarkan hasil uji validitas dan reliabilitas kinerja karyawan yang disajikan pada Tabel 2 menunjukkan bahwa nilai koefisien 
korelasi pada kolom uji validitas nilai koefisien korelasi dari 15indikator kinerja karyawan lebih besar dari batas minimal nilai ( $\mathrm{r}$ tabel) yaitu 0,514 . Sedangkan untuk nilai Cronbach Alpha pada kolom uji reliabilitas adalah sebesar 0,945 lebih besar dari 0,60. Dengan demikian untuk 15 indikator kinerja karyawan terkategori valid dan reliabel.

Tabel. 3 Hasil analisis Uji t $(\alpha=0,05)$

\begin{tabular}{|c|l|c|c|c|}
\hline $\begin{array}{c}\text { No } \\
\cdot\end{array}$ & $\begin{array}{l}\text { Variabel } \\
\text { Bebas }\end{array}$ & $t_{\text {hitung }}$ & $\begin{array}{c}\text { Probabilit } \\
\text { as }\end{array}$ & $\begin{array}{c}\text { Kesimpul } \\
\text { an }\end{array}$ \\
\hline 1. & $\begin{array}{l}\text { Fungsi- } \\
\text { Fungsi } \\
\text { Manajem } \\
\text { en }\end{array}$ & $\begin{array}{c}4,11 \\
0\end{array}$ & 0,001 & $\begin{array}{c}\text { Signifika } \\
\mathrm{n}\end{array}$ \\
\hline
\end{tabular}

Sumber : Data primer yang diolah, 2014

Berdasarkan tabel 3 diatas dapat di ketahui pengaruh secara parsial antara variabel bebas dengan variabel terikat yaitu pengaruh variabel fungsi-fungsi manajemen terhadap kinerja karyawan dapat ditunjukan pada hasil perhitungan tabel 8, dimana diketahui bahwa nilai $t_{\text {hitung }}=4,110$ pada taraf nyata $(\mathrm{p}=0,001<\alpha=0,05)$ atau $t_{\text {hitung }}$ $(4,110)>t_{\text {tabel }}(2,179)$ maka $\mathrm{H}_{\mathrm{o}}$ ditolak dan $\mathrm{H}_{\mathrm{a}}$ diterima. Angka tersebut menunjukkan bahwa fungsi-fungsi manajemen mempunyai pengaruh positif dan signifikan terhadap kinerja karyawan pada PT. Mandala Multi Finance di Kabupaten Luwu Utara .

\section{Pembahasan Hasil Penelitian}

Pada prinsipnya penelitian ini bertujuan untuk mencari jawaban terhadap rumusan masalah yang telah dikemukakan pada bagian sebelumnya, dimana pada intinya adalah untuk mengetahui pengaruh fungsi-fungsi manajemen terhadap kinerja karyawan pada PT. Mandala Multi Finance di Kabupaten Luwu Utara.

Dengan melibatkan sebanyak 15 responden, memberikan informasi mengenai pengaruh fungsi-fungsi manajmen terhadap kinerja karyawan.

Hasil penelitian menunjukkan bahwa secara parsial pengaruh variabel fungsi-fungsi manajemen terhadap kinerja karyawan dapat ditunjukan pada hasil perhitungan table 8 , dimana diketahui bahwa nilai $t_{\text {hitung }}=4,110$ pada taraf nyata $(\mathrm{p}=0,001<\alpha=0,05)$ atau $\mathrm{t}_{\text {hitung }}(4,110)>\mathrm{t}_{\text {tabel }}$ $(2,179)$ maka $\mathrm{H}_{\mathrm{o}}$ ditolak dan $\mathrm{H}_{\mathrm{a}}$ diterima. Angka tersebut menunjukkan bahwa fungsi-fungsi manajemen mempunyai pengaruh positif signifikan terhadap kinerja karyawan pada PT. Mandala Multi Finance di Kabupaten Luwu Utara dapat diterima.

Hasil penelitian ini sejalan dengan hasil penelitian yang dilakukan oleh Elfian (2013) dengan judul penelitian yaitu pengaruh penerapan fungsi-fungsi manajemen terhadap kinerja guru pada SDN 143 Arusu Kecamatan Malangke Barat Kabupaten Luwu Utara.Hasil penelitian menunjukkan bahwa secara parsial (Uji-t) bahwa variabel Fungsi-Fungsi Manajemen yang terdiri dari Planninig, Organization, Actuating, Controlling berpengaruh positif signifikan terhadap Kinerja Guru.

Kemudian menurut pendapat Flippo Edwin B. (1996:5-7) bahwa dalam menjalankan pekerjaan seharusnya organisasi memperhatikan fungsifungsi manajerial dan fungsi operasional.

\section{SIMPULAN}

Berdasarkan analisis data dengan menggunakan bantuan program statistik SPSS di peroleh persamaan regresi linear sederhana sebagai berikut $: \mathrm{Y}=8,585+0,752 \mathrm{X}$, artinya Nilai konstan sebesar 8,585 menunjukkan bahwa jika variabel bebas yaitu fungsi-fungsi manajemen tidak mengalami perubahan atau sama dengan nol, maka nilai kinerja karyawan pada PT. Mandala Multi Finance di Kabupaten Luwu Utara adalah sebesar 8,585. Nilai koefisien regresi variabel fungsi-fungsi manajemen sebesar 0,752 bernilai positif mempunyai arti bahwa jika penerapan fungsi-fungsi manajemen semakin baik maka itu akan meningkatkan kinerja karyawan sebesar 0,752 . Nilai koefisien korelasi sederhana sebesar 0,565 . Besar nilai korelasi ini mempunyai hubungan yang tergolong sedang dan posistif. Intreval koefisien 0,80-1,00 memiliki tingkat hubungan yang sangat kuat (sugiono, 2007:214). Nilai koefisien korelasi yang bernilai positif tersebut menunjukkan orientasi hubungan searah, dimana fungsi-fungsi manajemen semakin baik, maka akan meningkatkan kinerja karyawan. Nilai koefisien determinasi $\left(\mathrm{R}^{2}\right)$ diperoleh angka sebesar 0,532 , hal ini berarti bahwa $53,2 \%$ variasi dari naik turunya kinerja karyawan dapat dipengaruhi oleh fungsi-fungsi manajemen. 
Sedangkan sisanya sebesar 46,8 dipengaruhi oleh variabel lain yang tidak teranalisis dalam model penelitian ini. Secara parsial antara variabel bebas dengan variabel terikat yaitu pengaruh variabel fungsi-fungsi manajemen terhadap kinerja karyawan dapat ditunjukan pada hasil perhitungan tabel 8, dimana diketahui bahwa nilai thitung $=4,110$ pada taraf nyata $(\mathrm{p}=0,001<\alpha=0,05)$ atau $\mathrm{t}_{\text {hitung }}$ $(4,110)>t_{\text {tabel }}(2,179)$ maka $\mathrm{H}_{\mathrm{o}}$ ditolak dan $\mathrm{H}_{\mathrm{a}}$ diterima. Angka tersebut menunjukkan bahwa fungsi-fungsi manajemen mempunyai pengaruh positif dan signifikan terhadap kinerja karyawan pada PT. Mandala Multi Finance di Kabupaten Luwu Utara dapat diterima.

\section{DAFTAR PUSTAKA}

Dessler, Gary. 2003. Manajemen Sumber Daya Manusia, Jilid II. Jakarta: PT. Prenhalindo

Edwin B. Flippo. 1996. Manajeman Personalia. Jakarta: Erlangga

Edy, S. 2010. Manajemen Sumber Daya Manusia. Jakarta :PT Perdana Media Grob

Elfian. 2013. Pengaruh Penerapan Fungsi-Fungsi Manajemen Terhadap Kinerja Guru Pada SDN 143 Arusu Kecamatan Malangke Barat Kabupaten Luwu Utara. Skripsi. STIE Muhammadiyah Palopo

Gorda, N., I Gusti. 2006 Kepemimpinan, Ghalia. Jakarta

Ghozali, I. 2006. Aplikasi Analisis Multivariate Dengan Program SPSS. Semarang: Badan Penerbit Universitas Diponegoro.

Handoko, T. Hani.1999. Manajemen. Edisi kedua.

Hasibuan, Malayu S.P. 2001. Manajemen Sumberdaya Manusia. Jakarta : Bumi Aksara.

.2002. Manajemen Sumber Daya Manusia. Jakarta : Bumi Aksara

Mangkunegara, Anwar Prabu. 2001. Manajemen Sumber Daya Manusia Perusahaan. Bandung: Remaja Rosdakarya

2009. Manajemen Sumber Daya Manusia Perusahaan, Bandung: PT Remaja Rosdakarya Offset

Flippo Edwin B. 1996. Fungsi Operasional dan Manajerial

Ritonga, M.T. 2004. Kurikulum Berbasis Kompetensi. jilid 3.Jakarta ; Erlangga. PT. Gelora Aksara Pratama

Robbins. 2001. Karakteristik Responden
Sedarmayanti.2001 Sumber Daya Manusia dan Produktivitas Kerja. Bandung: CV. Mandar Maju.

Suliyanto. 2011. EKONOMETRIKA TERAPAN: Teori dan Aplikasi dengan SPSS. Yogyakarta: Andi.

Suprayitno Riyanto dan Sapar. 2011. Pengantar Metode Penelitian. Bogor: Makaira Printing Plus.

Wijayanto, Dian. 2012. Pengantar Manajemen. Jakarta: PT Gramedia Pustaka Utama 